\title{
Synthesis,Structural and Biological studies of 4-[(1-phenyl- 2,3-dimethyl-3-pyrozoline-5-one)azo]-N,N-dimethyl anline with some transition metal ions
}

\author{
Rehab A.M.Al-Hasani * \\ Received 6, May, 2008 \\ Acceptance 12, May, 2009
}

\begin{abstract}
:
The present work includes the preparation and characterization of $\{\mathbf{C o}(\mathbf{I I}), \mathbf{N i}(\mathbf{I I})$, Pd(II), Fe(III) , Ru(III), Rh(III), Os(III), Ir(III), Pt(IV) and VO(IV)\}complexes of a new ligand 4-[(1-phenyl-2,3-dimethyl-3-pyrozoline-5-one)azo]-N,Ndimethylanline (PAD). The product (PAD) was isolated,studies and characterized by phsical measurements,i.e., (FT-IR), (UV) Spectroscopy and elemental analysis(C.H.N). The prepared complexes were identified and their structural geometric were suggested in solid state by using flame atomic absorption, elemental analysis(C.H.N), (FT-IR) and (UV-Vis) Spectroscopy, as well as magnetic susceptibility and conductivity measurements . The study of the nature of the complexes formed in( ethanolic solution) following the mole ratio method,gave results which were compared successfully with those obtained from solid state studies. The apparent stability constant of the complexes have been studied with the time and their color were stable for more than ( 6 ) hours, as well as the molar absorptivities have been calculated.The antibacterial activity for the ligand (PAD) and their metal complexes were studied against two selected micro - organisms [(Klesbiella pneumonia) as gram negative] and[( Streptococcus faecalis) as gram positive]. Further more the antifungl activity against two micro-organism (Candida albicans and Aspergillus flavus) were studied for the ligand (PAD) and their metal complexes .
\end{abstract}

Key words: Azo compounds, Coordination compound of Azo, Synthesis and crystal structure of Azo compounds, Biological activity of Azo compounds .

\section{Introduction: -}

A series of N(1)-aryloxy (or thio) acetyl-3,5-dimethyl pyrazoles have been prepared in order to study their hypoglycemic and CNS activities[1,2].A slight reduction of blood sugar was observed when these compounds were screened on rats at an oral dose of $250 \mathrm{mg} / \mathrm{kg}$ body weight as well as some of these compounds were found CNS stimulant, relatively nontoxic,induced writhing and piloerections in albino mice ${ }^{(1)}$. Several $\mathrm{N}$-substituted $(\mathbf{3 , 5})$ or $(\mathbf{2 , 3})$-dimethyl pyrazoles have recently been known to display significant hypoglycemic activity[3,5]. Some compounds having $\mathbf{N}$-acyl and $\mathbf{N}$-aryloxyacetyl [1] moieties have also evinced substantial hypoglycemic efficacy.

The present paper describes the preparation of a new azo compound derivative from (1-phenyl-2,3dimethyl-4-amino-3-pyrozoline-5one), in an attempt to introduce the azo $(-\mathrm{N}=\mathrm{N}-)$ moiety in the structure of pyrozole ring to investigate the

*Al-Mustansirya University, College of Science, Department of Chemistry, Baghdad, Iraq. 
coordination behaviour of the new (PAD) ligand toward some transition metal ions $\{\mathbf{C o}($ II) $, \mathbf{N i}($ II $), \mathbf{P d}($ II), Fe(III), Ru(III), Rh(III), Os(III), $\operatorname{Ir}($ III), $\operatorname{Pt}(I V)$ and VO(IV)\}, which have been choosen to react with (PAD) and to compare the biological activity of (PAD) ligand and their metal complexes with the main ring structure.

\section{Material and Methods: \\ Physical measurements and analysis:-}

Melting points were recorded on GallenKamp melting point apparatus and were uncorrected. FT-IR spectra were recorded using FT-IR.8300 Shimadzu in the range of (4000-200) $\mathrm{cm}^{-1}$,samples were measured as (CsI disc ). Electronic spectra were obtained using UV-1650 PC Shimadzu Spectrophotometer at room temperature. The measurements were recorded using a concentration of $\mathbf{1 0}^{-}$ ${ }^{3} \mathbf{M}$ of the (PAD) ligand and their metal complexes in chloroform as a solvent.Microanalytical data for (C.H.N) were obtained using $1108 \mathrm{CHN}-\mathrm{O}$. The metal content was estimated Spectrophotometrically using Flame Atomic absorption Shimadzu A.A-670 Spectrophotometer. Conductivity measurements were obtained using Corning Conductivity Meter 220 with cell constant $\left(1 \mathrm{~cm}^{-1}\right)$, using DMF as a solvent and concentration of $10^{-3} \mathrm{M}$ at $25 \mathrm{C}^{\circ}$. Magnetic susceptibility measurements were obtained at $25 \mathrm{C}^{\circ}$ on the solid state applying Faraday's method using Bruker BM6 instrument.

\section{A-preparation of the AZO (PAD)ligand}

(PAD) was prepared using the general procedure[6] .1-phenyl-2,3-dimethyl-4amino-3-pyrozoline-5-

one $(2.54 \mathrm{gm}, 0.0142 \mathrm{~mol})$ was dissolved in $100 \mathrm{ml}$ of water and $10 \mathrm{ml}$ of concentrated hydrochloric acid and diazotized below $5 \mathrm{C}^{\circ}$ with $\mathrm{NaNO}_{2}(1 \mathrm{gm}, 0.0142 \mathrm{~mol})$.The resulting diazoniumchloride solution was mixed with N,N-dimethylanline $(1.72,0.0142 \mathrm{~mol})$ dissolved in alcoholic $\mathrm{NaOH}$ solution $(3 \mathrm{gm}, 100 \mathrm{ml})$ below $0 \mathrm{C}^{\circ}$. The mixture was left in the refrigerator over night, the solid product was filtered off, washed with cold water $250 \mathrm{ml}$ and crystallized from ethanol and dried over $\mathrm{CaCl}_{2}$.

\section{B-Preparation of the metal complexes (1-10)}

The metal complexes were prepared by mixing the ethanolic solutions of the (PAD) ligand $(0.01 \mathrm{~mol})$ with the appropriate metal ion salts $\left[\mathrm{CoCl}_{2} \cdot 6 \mathrm{H}_{2} \mathrm{O}, \mathrm{NiCl}_{2} \cdot 6 \mathrm{H}_{2} \mathrm{O}\right.$, $\mathrm{PdCl}_{2}\left(\mathrm{PhCN}_{2}, \mathrm{FeCl}_{3} .9 \mathrm{H}_{2} \mathrm{O}, \mathrm{RuCl}_{3}\right.$. $\mathrm{H}_{2} \mathrm{O}, \mathrm{RhCl}_{3} . \mathrm{H}_{2} \mathrm{O}, \mathrm{OsCl}_{3} . \mathrm{H}_{2} \mathrm{O}, \mathrm{IrCl} 3$. $\mathrm{H}_{2} \mathrm{O}, \quad \mathrm{H}_{2} \mathrm{PtCl}_{6} \cdot 6 \mathrm{H}_{2} \mathrm{O}$ and $\left.\mathrm{VOSO}_{4} .5 \mathrm{H}_{2} \mathrm{O}\right]$, $(0.01 \mathrm{~mol})$.The $\mathrm{pH}$ of the reaction mixture was adjusted to $~ 8$ and it was refluxed for (2-3hr.) on a water bath.The metal chelates precipitated on refluxing the reaction mixture were filtered, washed thoroughly with hot water then ethanol several times,till the filtrate was colourless .The colored precipitates were finally washed with pet.ether (60$80^{\circ}$ ) and then dried under vacuum .

\section{$\underline{C-S t u d y}$ of complex formation in solution}

Complexes of (PAD) with metal ions were studied in solution using ethanol as a solvent, in order to determined [M : (PAD)]ratio in the complex following Molar ratio method [7]. A series of solutions were prepared having a constant concentration [10$3 \mathrm{M}]$ of the metal ion and (PAD).The $[\mathrm{M}:(\mathrm{PAD})]$ ratio was determined from the relationship between the absorption of the absorbed light and the mole ratio of $[\mathrm{M}:(\mathrm{PAD})$. 
D- Stability constant of azo complexes

The stability constant (K)[7] of the (1:1) or (1:2) [Metal: (PAD)] complex were evaluated as fallows: Two sets of solutions were prepared, the first set of solutions were formulated to contain stoichiometric amount $(1 \mathrm{ml})$ of $\left(10^{-}\right.$ $\left.{ }^{3} \mathrm{M}\right)$ ligand to $(1 \mathrm{ml})$ of $\left(10^{-3} \mathrm{M}\right)$ of metal ion by placing in to a three series of $10 \mathrm{ml}$ volumetric flasks. The solutions of the coloured complexes were diluted to the mark with ethanol(As). The second set were formulated to contain five fold excess $(5 \mathrm{ml})$ of $\left(10^{-3} \mathrm{M}\right)$ ligand, by placing in to a three series of $(10 \mathrm{ml})$ volumetric flasks followed by addition of $(1 \mathrm{ml})$ of $\left(10^{-3} \mathrm{M}\right)$ of metal ion solution, the volumes were then completed to the mark with ethanol(Am). The absorbance (As and Am) of the solutions, were measured at $\lambda \mathbf{m a x}$ of maximum absorption. The stability constant (K) and the molar absorptivity $\left(\varepsilon_{\max }\right)$ have been calculated.

\section{E- Biological activity for (PAD) and its complexes}

The biological activity of the prepared (PAD) and their respective complexes were studied against selected types of bacteria which include[(Klesbiella pneumonia) as gram negative] and[( Streptococcus faecalis) as gram positive], were cultivated in Nutrient agar medium,as well as DMSO was used as a solvent and as a control, the concentrations of the compounds in this solvent were $10^{-}$ ${ }^{3} \mathrm{M}$, by using Disc Sensitivity Test $[8,9]$, this method involves the exposure of the zone of inhibition toward the diffusion of micro-organism on agar plate. The plates were incubated for $24 \mathrm{hr}$. at $37{ }^{\circ} \mathrm{C}$, the zone of inhibition of bacterial growth around the disc was observed.

In order to complete this study, the new (PAD) ligand and their metal complexes were tested for their in vitro growth inhibitory activity against a pathogenic fungi, i.e., (Candida albicans and Aspergillus flavus) on Potato dextrose agar medium and incubated at $30 \mathrm{C}^{\circ}$ for $72 \mathrm{hr}$., DMSO was used as a solvent and as a control, for both techniques, the concentration of the compounds in this solvent were $10^{-3} \mathrm{M}$. The inhibition of fugal growth, expressed in percentage terms, were determined on the growth in test plates compared to the respective control plates, as given by the Vincent equation [8-10], Table (5).

\section{Results and Discussion:- (A)-Elemental Analysis : -}

The analytical and physical properties of the (PAD) and its metal complexes are summarised in Table (1), indicate [1:1] [Metal:Ligand] stoichiometry in case [1- 4 and 10] complexes except [5-9] complexes where the molar ratio are [1:2] .The new (PAD) ligand was soluble in common organic solvents such as (ethanol,aceton and methanol) whereas the [1-10] of the new azo coloured crystallin solids complexes were soluble in $\left(\mathbf{C H}_{\mathbf{2}} \mathbf{C l}_{\mathbf{2}}, \mathbf{C H C l}_{\mathbf{3}}, \mathbf{D M F}\right.$ and DMSO)They are thermally stable and unaffected by atmospheric oxygen and moisture. The elemental analyses data are in agreement with the proposed stoichiometry. 


\begin{tabular}{|c|c|c|c|c|c|c|c|c|}
\hline \multirow{3}{*}{$\begin{array}{c}\text { Comp. } \\
\text { No. }\end{array}$} & \multirow{3}{*}{ Color } & \multirow{3}{*}{$\begin{array}{l}\text { Melting } \\
\text { Point } \mathbf{C}^{\circ}\end{array}$} & \multirow{3}{*}{$\begin{array}{l}\text { Yield } \\
\%\end{array}$} & \multirow{2}{*}{\multicolumn{4}{|c|}{$\begin{array}{c}\text { Elemental analyses } \\
\text { Found (Calc.) \% }\end{array}$}} & \multirow{3}{*}{$\begin{array}{l}\text { Suggested Formula for } \\
\text { isolated precipitate }\end{array}$} \\
\hline & & & & & & & & \\
\hline & & & & $\mathrm{C}$ & $\mathbf{H}$ & $\mathbf{N}$ & M & \\
\hline (PAD) & Orange & $187-189$ & 95 & $\begin{array}{c}68.34 \\
(68.05)\end{array}$ & $\begin{array}{c}5.93 \\
(6.27)\end{array}$ & $\begin{array}{c}20.07 \\
(20.89)\end{array}$ & - & $\mathrm{C}_{19} \mathrm{H}_{21} \mathrm{~N}_{5} \mathrm{O}$ \\
\hline [1] & Greenish-Blue & 208 & 84 & $\begin{array}{c}46.95 \\
(47.30)\end{array}$ & $\begin{array}{c}4.58 \\
(4.35)\end{array}$ & $\begin{array}{c}15.26 \\
(14.52)\end{array}$ & $\begin{array}{c}12.33 \\
(12.02)\end{array}$ & {$\left[\mathrm{Co}(\mathrm{PAD}) \mathrm{Cl}_{2}\right] . \mathrm{H}_{2} \mathrm{O}$} \\
\hline [2] & Reddish brown & 211 & 72 & $\begin{array}{c}44.71 \\
(45.53)\end{array}$ & $\begin{array}{c}3.44 \\
(4.19)\end{array}$ & $\begin{array}{c}13.82 \\
(13.98)\end{array}$ & $\begin{array}{c}10.77 \\
(11.72)\end{array}$ & {$\left[\mathrm{Ni}(\mathrm{PAD}) \mathrm{Cl}_{2}\right] .2 \mathrm{H}_{2} \mathrm{O}$} \\
\hline [3] & Brown & 215 & 86 & $\begin{array}{c}43.61 \\
(44.49)\end{array}$ & $\begin{array}{c}4.23 \\
(4.09)\end{array}$ & $\begin{array}{c}12.24 \\
(13.66)\end{array}$ & $\begin{array}{c}19.82 \\
(20.76)\end{array}$ & {$\left[\mathrm{Pd}(\mathrm{PAD}) \mathrm{Cl}_{2}\right]$} \\
\hline$[4]$ & Dark brown & 219 & 70 & $\begin{array}{c}25.04 \\
(25.21)\end{array}$ & $\begin{array}{c}3.60 \\
(2.32)\end{array}$ & $\begin{array}{c}7.11 \\
(7.74)\end{array}$ & $\begin{array}{c}6.49 \\
(6.17)\end{array}$ & {$\left[\mathrm{Fe}(\mathrm{PAD}) \mathrm{Cl}_{2}\left(\mathrm{H}_{2} \mathrm{O}\right)_{2}\right] . \mathrm{Cl} .2 \mathrm{H}_{2} \mathrm{O}$} \\
\hline [5] & Dull grey & 233 & 78 & $\begin{array}{c}52.88 \\
(51.96) \\
\end{array}$ & $\begin{array}{c}4.13 \\
(4.78)\end{array}$ & $\begin{array}{c}16.27 \\
(15.95)\end{array}$ & $\begin{array}{c}10.69 \\
(11.51)\end{array}$ & {$\left[\mathrm{Ru}(\mathrm{PAD})_{2} \mathrm{Cl}_{2}\right] \mathrm{Cl}$} \\
\hline [6] & Yellowish-red & 230 & 80 & $\begin{array}{c}50.07 \\
(50.81) \\
\end{array}$ & $\begin{array}{c}3.91 \\
(4.68)\end{array}$ & $\begin{array}{c}15.41 \\
(15.60) \\
\end{array}$ & $\begin{array}{c}11.58 \\
(11.46) \\
\end{array}$ & {$\left[\mathrm{Rh}(\mathrm{PAD})_{2} \mathrm{Cl}_{2}\right] \mathrm{Cl} . \mathrm{H}_{2} \mathrm{O}$} \\
\hline [7] & Blackish brown & 238 & 72 & $\begin{array}{c}43.77 \\
(44.67)\end{array}$ & $\begin{array}{c}4.02 \\
(4.11)\end{array}$ & $\begin{array}{c}12.89 \\
(13.71)\end{array}$ & $\begin{array}{c}18.13 \\
(18.63)\end{array}$ & {$\left[\mathrm{Os}(\mathrm{PAD})_{2} \mathrm{Cl}_{2}\right] \mathrm{Cl} .3 \mathrm{H}_{2} \mathrm{O}$} \\
\hline [8] & $\begin{array}{l}\text { Orangish- } \\
\text { red }\end{array}$ & 232 & 78 & $\begin{array}{c}43.21 \\
(42.99)\end{array}$ & $\begin{array}{c}3.17 \\
(3.95)\end{array}$ & $\begin{array}{c}3.84 \\
(3.95)\end{array}$ & $\begin{array}{c}18.01 \\
(18.12)\end{array}$ & {$\left[\operatorname{Ir}(\mathrm{PAD})_{2} \mathrm{Cl}_{2}\right]$ Cl. 2 EtOH } \\
\hline [9] & Dark red & 238 & 81 & $\begin{array}{c}46.19 \\
(45.27) \\
\end{array}$ & $\begin{array}{c}4.24 \\
(4.17) \\
\end{array}$ & $\begin{array}{c}14.46 \\
(13.90) \\
\end{array}$ & $\begin{array}{c}19.31 \\
(19.37) \\
\end{array}$ & {$\left[\mathrm{Pt}(\mathrm{PAD})_{2} \mathrm{Cl}_{2}\right] \mathrm{Cl}_{2}$} \\
\hline$[10]$ & Dark green & 220 & 83 & $\begin{array}{c}45.68 \\
(45.78)\end{array}$ & $\begin{array}{c}3.36 \\
(4.21)\end{array}$ & $\begin{array}{c}14.29 \\
(14.05)\end{array}$ & $\begin{array}{c}11.12 \\
(10.23)\end{array}$ & [VO (PAD) $\left.\mathrm{SO}_{4}\right]$ \\
\hline
\end{tabular}

\section{(B)-Infra red spectra : -}

The FT-IR.spectrum of the free (PAD) ligand was compared with the spectra of metal complexes and data is shown in Table (2).A strong bands is observed in the free (PAD) ligand at $\left(1568 \mathrm{~cm}^{-1}\right)$ and $\left(1775 \mathrm{~cm}^{-1}\right)$, which are assigned to $\mathbf{v N}=\mathbf{N}$ and $\mathbf{v} \mathbf{C}=\mathbf{O}$ respectively $[11,12]$.Coordination of the (PAD) ligand to the metal through the azo nitrogen atom and oxygen atom of the carbonyl group are expected to reduce the electron density in the azo and carbonyl links and lower the $\mathbf{v N}=\mathbf{N}$ and $\mathbf{v} \mathbf{C}=\mathbf{O}$ absorptions frequency.In the spectra of all the new azo complexes, the bands due to $\mathbf{v N}=\mathbf{N}$ and $\mathbf{v} \mathbf{C}=\mathbf{O}$ were shifted to lower frequencies $(1550-1556) \mathrm{cm}^{-1}$ and
(1763-1768) $\mathrm{cm}^{-1}$ respectively as is shown in table (2). On the basis of this evidence, it is concluded that (PAD) acts as bidentate ligand in all the complexes . In the far-infrared region the azo complexes exhibited bands around (513 - 520) $\mathrm{cm}^{-1},(460$ - 508) $\mathrm{cm}^{-1}$ and $(370-405) \mathrm{cm}^{-1}$, which are assignable to $\mathbf{v}(\mathbf{M}-\mathbf{O}), \mathbf{v}(\mathbf{M}-\mathbf{N})$ and $\mathbf{v}(\mathbf{M}$ - Cl) modes respectively[13]. A strong band was observed at $(978) \mathrm{cm}^{-1}$ due to $(\mathbf{v} \mathbf{V}=\mathbf{O})$ stretching mode in [10] complex[13], furthermore a band related to $\mathbf{S O}_{4}$ ) sulfate anion in the [10] complex was observed at (1504) $\mathrm{cm}^{-1}$, which indicated a bidentate behavior[13,14].

\section{Table (2)Characteristic Stretching Vibrational Frequencies $\left(\mathrm{cm}^{-1}\right)$ located} in the FT-IR of (PAD) and their metal complexes

\begin{tabular}{|c|c|c|c|c|c|c|}
\hline Comp.No. & $\mathrm{vN}=\mathrm{N}$ & $v \mathrm{C}=\mathrm{O}$ & vM-O & vM-N & vM-Cl & Others \\
\hline (PAD) & $1568(\mathrm{~s})$ & $1775(\mathrm{~s})$ & - & - & - & - \\
\hline [1] & $1553(\mathrm{~m})$ & $1763(\mathrm{~m})$ & 514(mw) & 483(mw) & $387(w)$ & 3453(vO-H of water) \\
\hline [2] & $1553(\mathrm{~m})$ & $1766(\mathrm{~m})$ & $516(\mathrm{mw})$ & $488(\mathrm{mw})$ & 401(w) & $3456(\mathrm{vO}-\mathrm{H}$ of water) \\
\hline [3] & $1556(\mathrm{~m})$ & $1763(\mathrm{~m})$ & 513(mw) & 504(mw) & $405(w)$ & - \\
\hline [4] & $1550(\mathrm{~m})$ & $1765(\mathrm{~m})$ & $520(\mathrm{mw})$ & $508(\mathrm{mw})$ & $398(w)$ & $\begin{array}{c}1615 \text { of coordinated } \mathrm{H}_{2} \mathrm{O} \\
3456 \text { (vO-H of water) }\end{array}$ \\
\hline [5] & $1552(\mathrm{~m})$ & $1763(\mathrm{~m})$ & $518(\mathrm{mw})$ & 495(mw) & $400(w)$ & - \\
\hline [6] & $1550(\mathrm{~m})$ & $1766(\mathrm{~m})$ & $516(\mathrm{mw})$ & 508(mw) & $403(w)$ & 3458 (vO-H of water) \\
\hline [7] & $1554(\mathrm{~m})$ & $1766(\mathrm{~m})$ & $519(\mathrm{mw})$ & $506(\mathrm{mw})$ & $405(w)$ & 3458(vO-H of water) \\
\hline [8] & $1552(\mathrm{~m})$ & $1764(\mathrm{~m})$ & $516(\mathrm{mw})$ & 508(mw) & $400(w)$ & 3511(vO-H of water) \\
\hline [9] & $1555(\mathrm{~m})$ & $1768(\mathrm{~m})$ & $520(\mathrm{mw})$ & 504(mw) & $405(w)$ & - \\
\hline [10] & $1550(\mathrm{~m})$ & $1766(\mathrm{~m})$ & $518(\mathrm{mw})$ & $500(\mathrm{mw})$ & - & $\begin{array}{l}1504 \text { of }\left(\mathrm{SO}_{4}\right) \text { anion } \\
\text { coordination }\end{array}$ \\
\hline
\end{tabular}

Where:-(s)=strong, $(\mathrm{m})=$ medium, $(\mathrm{mw})=$ medium week, $(\mathrm{w})=$ week

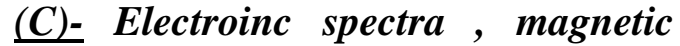
susceptibility and conductivity measurements :-

The electronic spectrum of the(PAD) 
ligand \{4-[(1-phenyl-2,3-dimethyl-3pyrozoline-5-one)azo]-N,N-dimethyl anline s shows an intense band at (40816) $\mathrm{cm}^{-1}$ with a weak shoulder at (36680) $\mathrm{cm}^{-1}$ followed by a strong intense band at (31125) $\mathrm{cm}^{-1}$ and (29411) $\mathrm{cm}^{-1}$. The first three bands may be due to $\left(\boldsymbol{\pi} \rightarrow \boldsymbol{\pi}^{*}\right)$ transitions, while the fourth band is due to $\left(\mathbf{n} \rightarrow \boldsymbol{\pi}^{*}\right)$ transitions which arises due to greater delocalisation of the $(\mathrm{C}=\mathrm{C}, \mathrm{C}=\mathbf{O}$ and $\mathrm{N}=\mathrm{N}) \boldsymbol{\pi}$ - electron resulting in a bathochromic shift[12,15].

The electronic spectra of the [110] metal complexes solutions in chloroform were recorded in the range (200 - 1100) nm and the data of these complexes are reported in Table(3).

[1]:-The greenish-blue cobalt(II) complex gave a magnetic moment value of (4.53)B.M, which indicates a high-spin type complex.Electronic spectrum in chloroform solvent exhibited a splitted band in the range of (17452-14184) $\mathrm{cm}^{-1}$ [16,17], Fig. (1) .These bands can be assigned to the transition ${ }^{\mathbf{4}} \mathbf{A}_{\mathbf{2}} \rightarrow{ }^{\mathbf{4}} \mathbf{T}_{\mathbf{1}}$ (p) $\left(\mathbf{v}_{\mathbf{3}}\right)$.A broad band was observed at $3244 \mathrm{~cm}^{-1}$ in infrared spectrum can be assigned to the ${ }^{\mathbf{4}} \mathbf{A}_{\mathbf{2}} \rightarrow{ }^{\mathbf{4}} \mathbf{T}_{\mathbf{2}}$ (f) $\left(\mathbf{v}_{\mathbf{1}}\right)$, while the transition of $\left(\mathbf{v}_{\mathbf{2}}\right)$ expected in the range (5000 - 6000) $\mathrm{cm}^{-1}$ can not be measured[18].The various ligand field parameters $\left(\mathbf{1 0 D q}, \mathrm{B}^{-}\right.$and $\mathbf{v}_{\mathbf{2}}$ ) have been calculated by refered to TanabaSugano diagram for $\left(\mathbf{d}^{\mathbf{7}}\right)$ configuration[19-21], to be (3244, $\mathbf{7 2 0 . 8}$ and 5453) respectively,as well as the calculation of the spin-orbit coupling constant $\left(\lambda^{-}\right)$was calculated .The resulting value $\left(\lambda^{-}=\mathbf{- 1 9 8 . 4}\right)$ show the present complex to be distorted tetrahedral[20,22]. The nephelauxetic factor $(\boldsymbol{\beta})$ was calculated and found to be (0.64) indicating high degree of covalence in bonding of ligand donor atoms with cobalt (II) ion[21,22].The molar conductance showed that the complex was nonelectrolyte, table(3) .
[2]:-The nickel (II) complex is diamagnetic suggesting square planar geometry. The electronic spectrum of Ni(II) complex shows two main absorption bands, at $(18520) \mathrm{cm}^{-1}$ and (25000) $\mathrm{cm}^{-1}$, which are assigned to ${ }^{\mathbf{1}} \mathbf{A}_{\mathbf{1 g}}$ $\rightarrow{ }^{1} \mathbf{A}_{\mathbf{2 g}}$ and ${ }^{1} \mathbf{A}_{1 \mathrm{~g}} \rightarrow{ }^{\mathbf{1}} \mathbf{B}_{1 \mathrm{~g}}$ transition respectively ,in a square planar disposition[17,19,23-25]. Conductivity measurement in (DMF) showed that the complex was non conducting behavior, table (3).

[3]:-The prepared brown $\mathrm{Pd}$ (II) complex showed a strong charge transfer band at (29630) $\mathrm{cm}^{-1}$, as well as two ligand field bands at (22580) $\mathrm{cm}^{-1}$ and (26334) $\mathrm{cm}^{-1}$ which may be assigned to :- ${ }^{\mathbf{1}} \mathbf{A}_{\mathbf{1 g}} \rightarrow{ }^{\mathbf{1}} \mathbf{B}_{\mathbf{1 g}}$ and ${ }^{\mathbf{1}} \mathbf{A}_{\mathbf{1 g}} \rightarrow$ ${ }^{1} \mathbf{E}_{\mathbf{g}}$, respectively, in a square planar environment $[19,22,26]$. The magnetic moment value was (0.82)B.M. Conductivity measurement in (DMF) showed that the complex was non ionic, table (3).

[4]:-The Fe(III) complex displays three main absorption bands which are assigned to :- ${ }^{\mathbf{6}} \mathbf{A}_{1 \mathrm{~g}} \rightarrow{ }^{\mathbf{4}} \mathbf{T}_{1 \mathrm{~g}}, \quad{ }^{\mathbf{6}} \mathbf{A}_{1 \mathrm{~g}}$ $\rightarrow{ }^{4} \mathbf{T}_{2 \mathrm{~g}},(\mathbf{P A D}) \rightarrow$ Fe $(\mathbf{C . T})$, transition $[16,19,23]$ respectively. The ligand field parameters calculated[19,21,24] for this complex

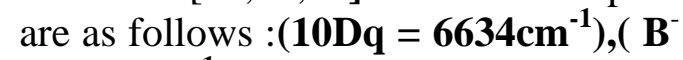
$\left.=620 \mathrm{~cm}^{-1}\right)$ and $(\beta=0.45)$. The magnetic moment is (5.83)B.M. with five unpaired electrons and an octahedral configuration [23,24]. Conductivity measurement showed that the complex was to be ionic ,table(3).

[5]:- The spectrum of this complex exhibited four absorption bands at $(15898,19708,27568$ and 35144$) \mathrm{cm}^{-}$ ${ }^{1}$. These bands correspond to those of octahedral

$\mathrm{Ru} \quad$ (III) complexes[19,21,26-28], and were assigned to :-

$$
{ }^{2} \mathbf{T}_{2 \mathrm{~g}} \rightarrow{ }^{2} \mathbf{E}_{\mathrm{g}}{ }^{\mathbf{4}} \mathbf{T}_{1 \mathrm{~g}} \quad,{ }^{2} \mathbf{T}_{\mathbf{2 g}} \rightarrow{ }^{\mathbf{2}} \mathbf{T}_{\mathbf{2 g}} \quad{ }^{\mathbf{2}} \mathbf{T}_{\mathbf{2 g}}
$$
transitions[16,19] respectively. The value of (10Dq and $\mu_{\text {eff }}$ )came out 
(27568 and 1.69) respectively, revealing inner-orbital low-spin distorted octahedral stereochemistry of the ligand around $\mathrm{Ru}(\mathrm{III})$ ion[29]. Coductivity measurement showed that complex was ionic, table (3).

[6]:-Electronic spectrum of the yellowish - red [6] complex in chloroform solution, showed four absorption bands, the first band as a weak shoulder at (18203) $\mathrm{cm}^{-1}$,a second band as a broad one at (20812) $\mathrm{cm}^{-1}$ and the last two absorption bands as a shoulder at (23122) and (25068) $\mathrm{cm}^{-1}$, which might be assigned to the transitions :- ${ }^{1} \mathbf{A}_{\mathbf{1 g}} \rightarrow{ }^{3} \mathbf{T}_{\mathbf{1 g}},{ }^{1} \mathbf{A}_{\mathbf{1 g}} \rightarrow$ ${ }^{3} \mathbf{T}_{\mathbf{2 g}},{ }^{1} \mathbf{A}_{1 \mathrm{~g}} \rightarrow{ }^{1} \mathbf{T}_{1} \mathbf{g}$ and ${ }^{{ }^{1}} \mathbf{A}_{1 \mathrm{~g}} \rightarrow{ }^{1} \mathbf{T}_{2 \mathrm{~g}}$ respectively ,which came in accordance with the published data for octahedral $\mathbf{R h}(\mathbf{I I I}) \quad$ complexes $[22,26,28]$. The band at $23122 \mathrm{~cm}^{-1}$ can be taken as (10Dq) value[18,19,22]. Magnetic moment of solid complex ,table(3) ,showed a higer orbital contribution.Conductivity

measurement in DMF showd that the complex was ionic, table (3).

[7]:-The spectral behavior of this complex ,table(3), is identical with that of [4] complex, which agree with octahedral geometry around Os(III) complex $[19,24,30]$.The magnetic moment that was measured at room temperature was found to be (1.98)B.M.this value refer to high spin complex, which is the only case in octahedral environment $[24,30]$. The conductance measurement indicate that the complex to be ionic ,table (3) .

[8]:-The electronic spectrum of the prepared orange-red $\mathbf{I r}$ (III) complex in chloroform solution, showed three absorption bands at $(17625,22280$ and 25461) $\mathrm{cm}^{-1}$, which might be assigned to the transitions :- ${ }^{1} \mathbf{A}_{1 \mathrm{~g}} \rightarrow{ }^{3} \mathbf{T}_{1 \mathrm{~g}}$, ${ }^{1} \mathbf{A}_{1 \mathrm{~g}} \rightarrow{ }^{1} \mathbf{T}_{1} \mathbf{g}$ and ${ }^{1} \mathbf{A}_{1 \mathrm{~g}} \rightarrow{ }^{1} \mathbf{T}_{\mathbf{2 g}}$, respectively ,these indicate an octahedral geometry[19,31] .The different ligand parameters (10Dq, B and $\boldsymbol{\beta})$ have been calculated using Tanaba-Sugano diagram of $\left(\mathbf{d}^{6}\right)$ system and found to be (24160, 270 and 0.41) respectively[19-21].The observed high magnetic moment value(1.83B.M.) of the present $\operatorname{Ir}(\mathrm{III})$ $\left(d^{6}\right)$ configuration ,which agree with octahedral geometry around $\operatorname{Ir}(\mathrm{III})$, this result indicate a higher orbital contribution around metal ion[19,31]. Conductivity measurement in DMF showed that the complex was to be ionic , table (3).

[9]:-The spectral and magnetic moment behaviors of this complex is identical with that of [6] and [8] complexes, which agree with octahedral geometry around $\mathbf{P t}(\mathbf{I V})$ complex[18,19,21]

table(3).Conductivity measurements in $\operatorname{DMF}\left(182.18 \mu \mathbf{s . c m}^{-1}\right) \quad$ showed electrolytic nature of 1:2.

[10]:-The electronic spectrum of vanadium (IV) complex, showed three prominent (d-d) absorption bands, the first one as a strong broad band at (11130) $\mathrm{cm}^{-1}$, and the second and third bands as a weak shoulders at (19053 and 24112) $\mathrm{cm}^{-1}$,these bands can be attributed to the following transitions $:{ }^{2} \mathbf{B}_{2 \mathrm{~g}} \rightarrow{ }^{2} \mathbf{E}_{\mathrm{g}} \quad,{ }^{2} \mathbf{B}_{2 \mathrm{~g}} \rightarrow{ }^{2} \mathbf{B}_{1 \mathrm{~g}}$, and ${ }^{2} \mathbf{B}_{2 \mathrm{~g}} \rightarrow{ }^{2} \mathbf{A}_{\mathbf{1 g}} \quad$ respectively $[14,16,19,22]$. The magnetic moment (1.98B.M) is higher than spin value of the vanadium metal only, this result indicates a higher orbital contribution $[19,22]$.These transitions and magnetic moment value came in accordance with the published data for square pyramidal VO(IV) complexes $[14,19,22]$. Conductivity measurement in DMF showed that the complex was non-ionic, Fig. (2), table(3).
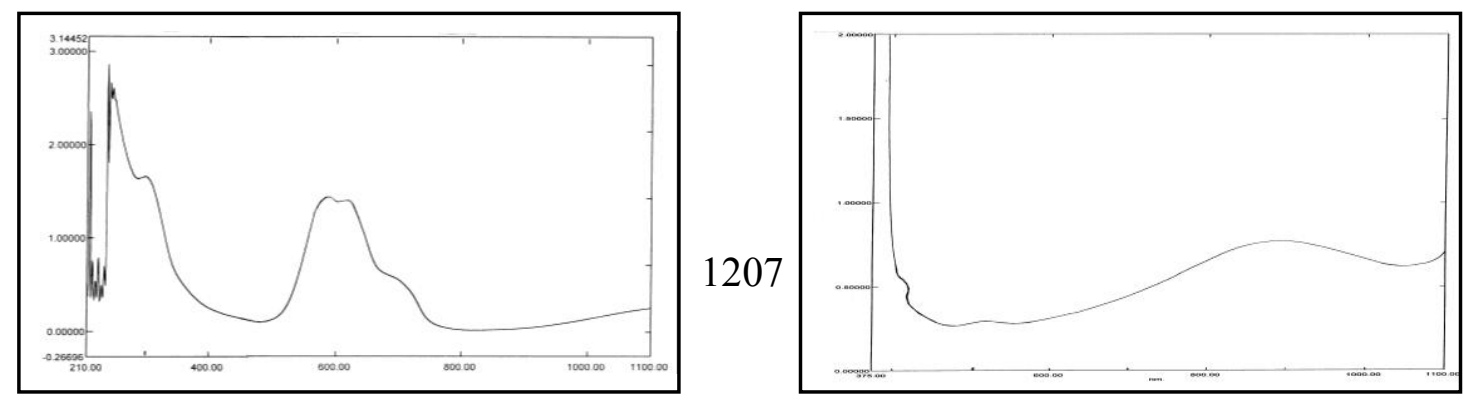
Table (3) Electronic Spectra $\left(\mathrm{CHCl}_{3}\right)$, Conductance (in DMF), and Magnetic moment (B.M) for Azo metal complexes

\begin{tabular}{|c|c|c|c|c|c|}
\hline $\begin{array}{l}\text { Comp } \\
\text { No. }\end{array}$ & $\begin{array}{c}\text { Bands } \\
\mathbf{c m}^{-1}\end{array}$ & Assignment & $\begin{array}{l}\text { Molar } \\
\text { cond. } \\
\mu_{\text {S.cm }} \\
{ }_{\text {.mol }}{ }^{-1}\end{array}$ & $\begin{array}{c}\mu \\
\text { eff. } \\
\text { B.M }\end{array}$ & $\begin{array}{l}\text { Suggested } \\
\text { Structure }\end{array}$ \\
\hline [1] & $\begin{array}{c}3244 \\
5453 \text { (cal) } \\
15733 \text { (av.) }\end{array}$ & $\begin{aligned} &{ }^{4} \mathrm{~A}_{2} \longrightarrow{ }^{4} \mathrm{~T}_{2}(\mathrm{~F}) \\
&{ }^{4} \mathrm{~A}_{2} \longrightarrow{ }^{4} \mathrm{~T}_{1(\mathrm{~F})} \\
&{ }^{4} \mathrm{~A}_{2} \longrightarrow{ }^{4} \mathrm{~T}_{1(\mathrm{P})}\end{aligned}$ & 13.02 & 4.53 & Tetrahedral \\
\hline [2] & $\begin{array}{l}18520 \\
25000\end{array}$ & $\begin{array}{l}{ }^{1} \mathrm{~A}_{1 \mathrm{~g}} \longrightarrow{ }^{1} \mathrm{~A}_{2 \mathrm{~g}} \\
{ }^{1} \mathrm{~A}_{1 \mathrm{~g}} \longrightarrow{ }^{1} \mathrm{~B}_{1 \mathrm{~g}}\end{array}$ & 18.32 & 0.36 & Square planer \\
\hline [3] & $\begin{array}{l}22580 \\
26334 \\
29630 \\
\end{array}$ & $\begin{aligned}{ }^{1} \mathrm{~A}_{1} \mathrm{~g} \longrightarrow{ }^{1} \mathrm{~B}_{1} \mathrm{~g} \\
{ }^{1} \mathrm{~A}_{1} \mathrm{~g} \longrightarrow{ }^{1} \mathrm{Eg} \\
(\mathrm{PAD})\end{aligned}$ & 11.68 & 0.14 & Square planer \\
\hline [4] & $\begin{array}{l}15084 \\
17811 \\
29344\end{array}$ & $\begin{aligned}{ }^{6} \mathrm{~A}_{1} \mathrm{~g} & \longrightarrow{ }^{4} \mathrm{~T}_{1} \mathrm{~g} \\
{ }^{6} \mathrm{~A}_{1} \mathrm{~g} & \longrightarrow{ }^{4} \mathrm{~T}_{2} \mathrm{~g} \\
& \longrightarrow \mathrm{Ce} \text { (C.T) }\end{aligned}$ & 68.58 & 5.83 & Octahedral \\
\hline [5] & $\begin{array}{l}15898 \\
19708 \\
27568 \\
31144\end{array}$ & $\begin{aligned} &{ }^{2} \mathrm{~T}_{2} \mathrm{~g} \longrightarrow{ }^{4} \mathrm{~T}_{1} \mathrm{~g} \\
&{ }^{2} \mathrm{~T}_{2} \mathrm{~g} \longrightarrow{ }^{4} \mathrm{~T}_{2} \mathrm{~g} \\
&{ }^{2} \mathrm{~T}_{2} \mathrm{~g} \longrightarrow{ }^{2} \mathrm{Eg} \\
&{ }^{2} \mathrm{~T}_{2} \mathrm{~g} \longrightarrow{ }^{2} \mathrm{~A}_{1} \mathrm{~g}\end{aligned}$ & 70.15 & 1.69 & Octahedral \\
\hline [6] & $\begin{array}{l}18203 \\
20812 \\
23122 \\
25068 \\
\end{array}$ & $\begin{aligned}{ }^{1} \mathrm{~A}_{1} \mathrm{~g} \longrightarrow{ }^{3} \mathrm{~T}_{1} \mathrm{~g} \\
{ }^{1} \mathrm{~A}_{1} \mathrm{~g} \longrightarrow{ }^{3} \mathrm{~T}_{2} \mathrm{~g} \\
{ }^{1} \mathrm{~A}_{1} \mathrm{~g} \longrightarrow{ }^{1} \mathrm{~T}_{1} \mathrm{~g} \\
{ }^{1} \mathrm{~A}_{1} \mathrm{~g} \longrightarrow{ }^{1} \mathrm{~T}_{2} \mathrm{~g}\end{aligned}$ & 70.15 & 1.69 & Octahedral \\
\hline [7] & $\begin{array}{l}16811 \\
18238 \\
31480\end{array}$ & $\begin{aligned}{ }^{6} \mathrm{~A}_{1} \mathrm{~g} & \longrightarrow{ }^{4} \mathrm{~T}_{1} \mathrm{~g} \\
{ }^{6} \mathrm{~A}_{1} \mathrm{~g} & \longrightarrow{ }^{4} \mathrm{~T}_{2} \mathrm{~g} \\
(\mathrm{PAD}) & \longrightarrow{ }^{\mathrm{O}}(\mathrm{C} . \mathrm{T})\end{aligned}$ & 75.39 & 1.98 & Octahedral \\
\hline [8] & $\begin{array}{l}17625 \\
22280 \\
25461 \\
\end{array}$ & $\begin{array}{l}{ }^{1} \mathrm{~A}_{1} \mathrm{~g} \longrightarrow{ }^{3} \mathrm{~T}_{1} \mathrm{~g} \\
{ }^{1} \mathrm{~A}_{1} \mathrm{~g} \longrightarrow{ }^{1} \mathrm{~T}_{1} \mathrm{~g} \\
{ }^{1} \mathrm{~A}_{1} \mathrm{~g} \longrightarrow{ }^{1} \mathrm{~T}_{2} \mathrm{~g} \\
\end{array}$ & 70.73 & 1.83 & Octahedral \\
\hline [9] & $\begin{array}{l}18998 \\
24023 \\
30158\end{array}$ & $\begin{aligned}{ }^{1} \mathrm{~A}_{1} \mathrm{~g} & \longrightarrow{ }^{3} \mathrm{~T}_{1} \mathrm{~g} \\
{ }^{1} \mathrm{~A}_{1} \mathrm{~g} & \longrightarrow{ }^{1} \mathrm{~T}_{2} \mathrm{~g} \\
{ }_{\mathrm{PAD})} & \longrightarrow \mathrm{C} . \mathrm{T})\end{aligned}$ & 182.18 & 2.04 & Octahedral \\
\hline [10] & $\begin{array}{l}11130 \\
19053 \\
24112\end{array}$ & $\begin{array}{l}{ }^{2} \mathrm{~B}_{2} \mathrm{~g} \longrightarrow{ }^{2} \mathrm{Eg} \\
{ }^{2} \mathrm{~B}_{2} \mathrm{~g} \longrightarrow{ }^{2} \mathrm{~B}_{1} \mathrm{~g} \\
{ }^{2} \mathrm{~B}_{2} \mathrm{~g} \longrightarrow{ }^{2} \mathrm{~A}_{1} \mathrm{~g}\end{array}$ & 10.25 & 1.98 & Square pyramideal \\
\hline
\end{tabular}

\section{Molar ratio and Stability constant} for Azo metal complexes :-

The molar ratio method was follow to determine the [M:(PAD)] ratio. The results of complex in ethanol as a solvent, table (4), suggest that the metal to ligand ratio was [1:1] for [1-4 and 10] complexes, while [1:2] for [5-9] complexes, which were comparable to those obtained from solid state study, table(1). 
Chelate stability constant (K) \{eq.(1) and (2) $\}$, as well as molar absorptivity $\left(\boldsymbol{\varepsilon}_{\max }\right) \quad\{$ eq.(3) $\}$ for all complexes were obtained spectrophotometrically by using the following equations :-

$\mathrm{K}=\left(1-\alpha / \alpha^{2} \mathrm{C}\right)$ Where[1:1]of [M:(PAD)]...(1)

$\mathrm{K}=\left(\mathbf{1 - \alpha} / 4 \alpha^{3} \mathrm{C}\right)$ Where[1:2] of [M:(PAD)]...(2)

$\mathbf{A m}=\left(\varepsilon_{\max } \mathbf{b C}\right) \ldots(3)$

The degree of dissociation $(\boldsymbol{\alpha})$ for the complex is obtained from the relation ship (4).

$\alpha=(\mathrm{Am}-\mathrm{As} / \mathrm{Am}) \ldots .(4)$

Where (As) and (Am) are the absorption of the partially and fully formed complex respectively at optimum concentration and $(\lambda \max )$ of maximum absorption, Fig. (3), table (4).

The results in Table(4), show that mole ratio of (1:2) for [5-9] complexes yielded rather high, this probably due to the presence of a bulk aromatic groups and a higher oxidation state of the metal ions. As well as the developed color for all complexes become stable after one hour up to six hours.
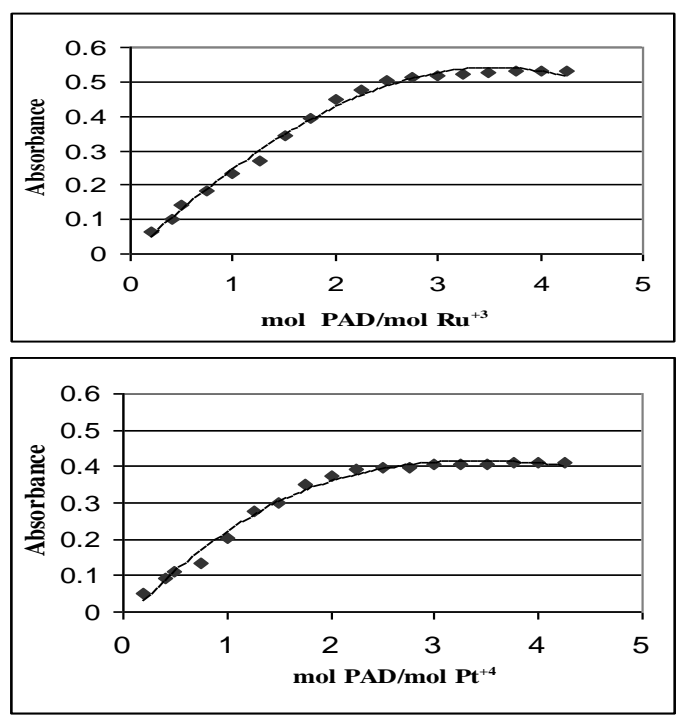

Fig. (3): - Mole ratio plot of (PADD) complexes (5 and 9)

Table (4) Molar ratio,Stability constant and Molar absorptivities of Azo metal complexes at room temperature

\begin{tabular}{|c|c|c|c|c|c|c|c|}
\hline Complex & {$[M:(P A D)$} & $A_{s}$ & $A m$ & $\begin{array}{c}K \\
\text { L. } m o l^{-1}\end{array}$ & $\underset{\operatorname{L.mol}^{-1} \mathrm{~cm}^{-1}}{\max }$ & $\alpha$ & $\begin{array}{c}\lambda \max \\
n m\end{array}$ \\
\hline [1] & $1: 1$ & 0.278 & 0.308 & $9.59 * 10^{5}$ & 3081 & 0.097 & 571 \\
\hline [2] & $1: 1$ & 0.373 & 0.428 & $6.32 * 10^{10}$ & 4281 & 0.128 & 660 \\
\hline [3] & $1: 1$ & 0.398 & 0.453 & $6.00 * 10^{5}$ & 4532 & 0.121 & 403 \\
\hline [4] & $1: 1$ & 0.356 & 0.409 & $2.42 * 10^{5}$ & 4093 & 0.130 & 486 \\
\hline [5] & $1: 2$ & 0.495 & 0.551 & $2.18 * 10^{10}$ & 5511 & 0.101 & 408 \\
\hline [6] & $1: 2$ & 0.294 & 0.336 & $4.48 * 10^{10}$ & 3363 & 0.125 & 432 \\
\hline [7] & $1: 2$ & 0.355 & 0.403 & $1.62 * 10^{10}$ & 3090 & 0.119 & 443 \\
\hline [8] & $1: 2$ & 0.259 & 0.309 & $5.03 * 10^{9}$ & 3106 & 0.161 & 418 \\
\hline [9] & $1: 2$ & 0.374 & 0.418 & $1.93 * 10^{10}$ & 6682 & 4180 & 515 \\
\hline [10] & $1: 1$ & 0.324 & 0.378 & $4.25 * 10^{5}$ & 5720 & 3785 & 756 \\
\hline
\end{tabular}

Structure of $[P A D]$ and it's Complexes [1-10]:-

According to the results obtained , the structure of the above mentioned [PAD] and [1-10] their complexes can be illustrated as follow :- 

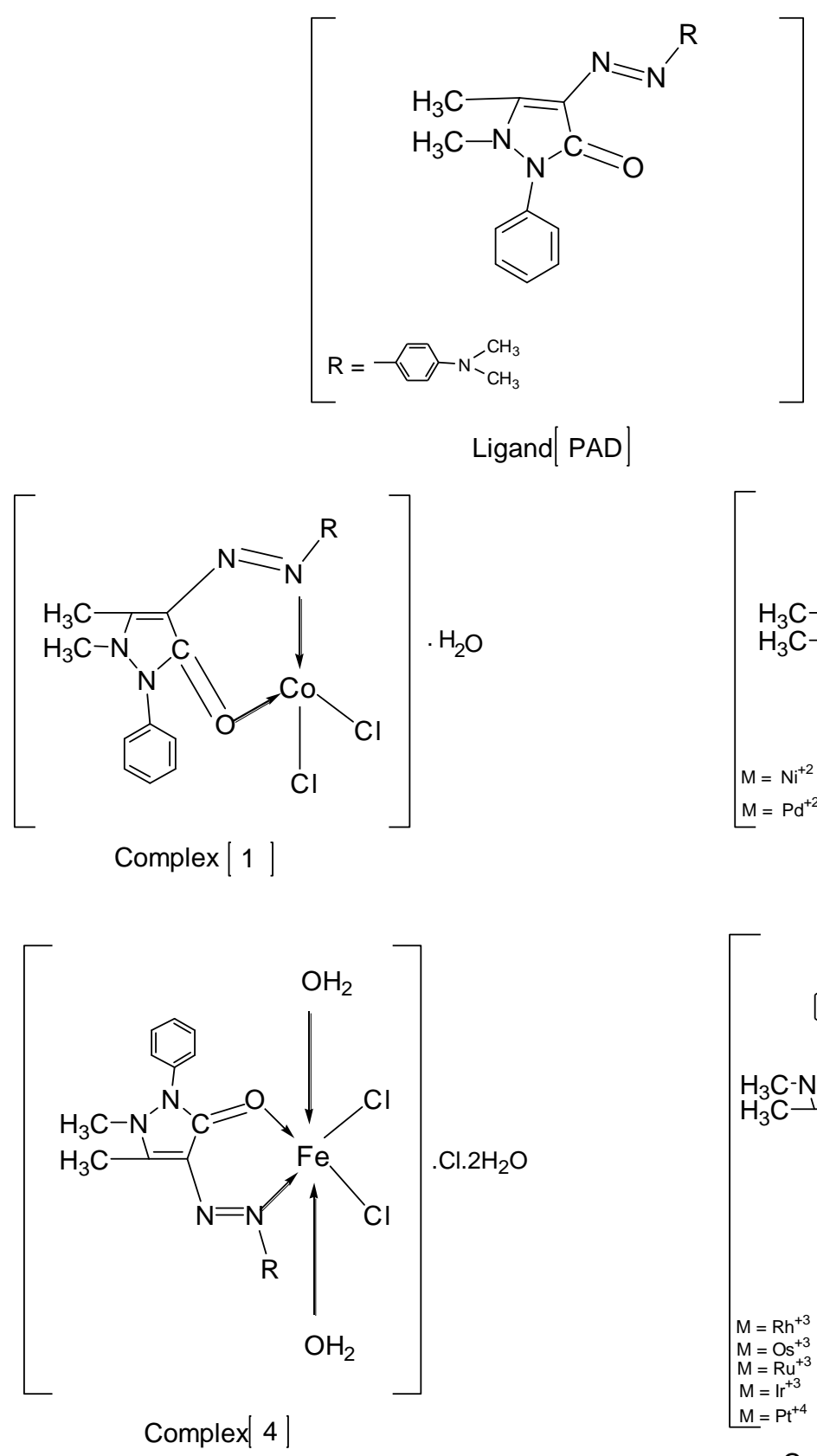

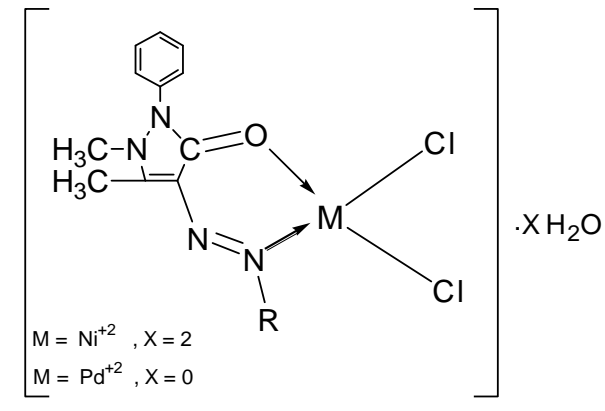

Complexes| 2,3]

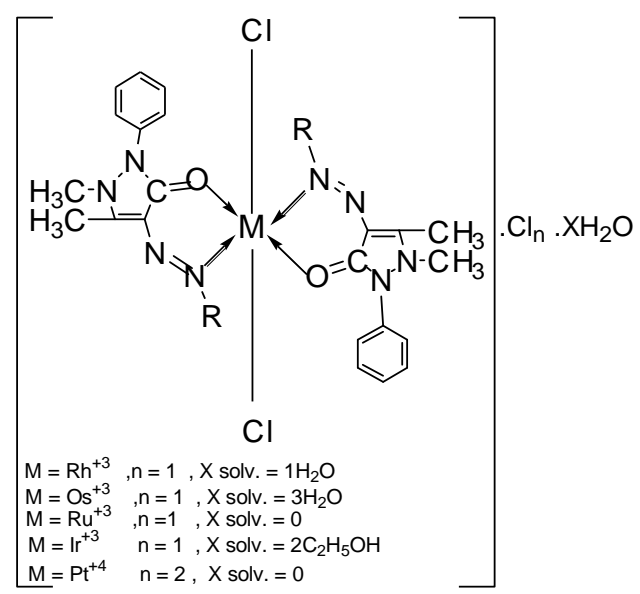

Complexes $[5,6,7,8$, and 9$]$

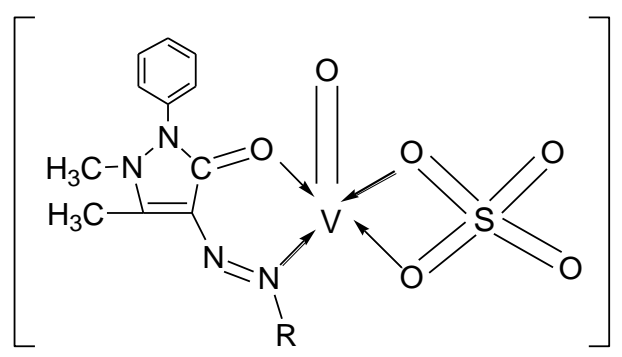

$$
\text { Complex }[10]
$$

\section{Antimicrobial activities:-}

The azo (PAD) ligand and [110]their metal chelates were screend in vitro in order to evaluate their antibacterial action against[(Klesbiella pneumonia) as gram negative] and[( Streptococcus faecalis) as gram positive] species as wll as antifungl activity against two micro-organism 
(Candida albicans and Aspergillus flavus) ,table (5) at two different concentration. The results from these studies ,showed the followings:-

1) All the azo metal complexes are more toxic as compared with their [PAD] parent ligand against the same micro-organsim and under the identical experimental conditions, table (5).

2) The increase in the antibacterial and antifungal activites of metal chelates may be due to the effect of the metal ion on the normal cell process. The toxicity also increases with the increasing concentration of test solution containing the new azo complexes .These activities may be explained by Tweedy,s Chelation Theory [34,35] .
3). The[1,2 and 10] complexes showed a moderate activities , while [3-9] complexes exhibited a great enhancement of activity against types of bacteria, Table (6). This difference in synergistic effect between the metal ion and the ligand molecule may be attributed to many factors, of these in that [3-9] complexes are considered to be a hard metal ions making their complexes to be less lipophilic, which relatively retard their permeation through the lipid part of the cell membrane. On the other hand the $[\mathbf{1}$ and 2] are considered to be soft metal ions, which render their complexes to be more lipophilic and will facilitate the penetration through the cell wall and affect the invironment of cells.

Table (5) Antibacterial and antifungal activities data for the Azo metal complexes and their parent (PAD) ligand

\begin{tabular}{|c|c|c|c|c|c|c|c|c|}
\hline \multirow[b]{2}{*}{ Compo. } & \multicolumn{2}{|c|}{ Klesbiella pneumonia } & \multicolumn{2}{|c|}{ Streptococcus faecali } & \multicolumn{2}{|c|}{ Aspergillus flavus } & \multicolumn{2}{|c|}{ Candida albicans } \\
\hline & $\begin{array}{c}100 \\
\text { ppm }\end{array}$ & $\begin{array}{c}200 \\
\text { ppm }\end{array}$ & $\begin{array}{c}100 \\
\text { ppm }\end{array}$ & $\begin{array}{c}200 \\
\text { ppm }\end{array}$ & $\begin{array}{c}100 \\
\text { ppm }\end{array}$ & $\begin{array}{c}200 \\
\text { ppm }\end{array}$ & $\begin{array}{c}100 \\
\text { ppm }\end{array}$ & $\begin{array}{c}200 \\
\text { ppm }\end{array}$ \\
\hline Control (DMSO) & - & & - & & & - & & - \\
\hline (PAD) & 6 & 10 & - & 6 & 35 & 27 & 40 & 30 \\
\hline [1] & 6 & 12 & 8 & 10 & 30 & 18 & 20 & 15 \\
\hline [2] & 8 & 12 & 10 & 16 & 31 & 20 & 25 & 20 \\
\hline [3] & 10 & 16 & 8 & 10 & 27 & 18 & 23 & 14 \\
\hline [4] & 6 & 14 & 10 & 16 & 24 & 12 & 20 & 11 \\
\hline [5] & 6 & 18 & 6 & 10 & 22 & 16 & 27 & 15 \\
\hline [6] & 8 & 10 & 6 & 12 & 30 & 18 & 22 & 16 \\
\hline [7] & 6 & 8 & 8 & 18 & 25 & 12 & 31 & 23 \\
\hline [8] & 8 & 12 & 10 & 16 & 22 & 16 & 18 & 13 \\
\hline [9] & 10 & 16 & 6 & 20 & 20 & 18 & 20 & 11 \\
\hline [10] & 6 & 8 & 8 & 10 & 30 & 23 & 21 & 18 \\
\hline \multicolumn{5}{|c|}{ Where :[6-8: $(+), 8-10:(++),>10:(+++)]$} & \multicolumn{4}{|c|}{ 30-40: $(+++), 20-30:(++++), 10-20:(+++++)$} \\
\hline
\end{tabular}

\section{References:-}

1.Husain,M.I. and Srivastava,G.C., 1979. "Synthesis of N-aryloxy (or thio) acetyl acetamido pyrazoles» ,J.Ind.Chem.Soc.,LVI(3), 14-18.

2.Siddiqui,Z.A., 1990.«Synthesis and Characterization of the complexes of 5-amino-4-cyanopyrazole with $\mathrm{Cr}(I I I), \mathrm{Mn}(I I), \mathrm{Zn}(I I), \mathrm{Cd}(I I)$ and $\mathrm{Hg}$ (II)»,Ind.J.Chem.,29A(1),111-117.

3.Cotton,F.A. and Wilkinson,G., 1986. «Advanced Inorganic Chemistry» , $4^{\text {th }}$ Ed.,Wiley Eastern Private Ltd.,pp198.
4.Eichhorn,G.L. and marzilli, L.G., 1998. «Advanced Inorganic Biochemistry,models in inorganic chemistry»,PTR prentice-Hall,Inc., pp92.

5.Al-Hamadani, A.A.S., 2005. «Synthesis and Characterization of $\mathrm{Co}(I I), \mathrm{Ni}(I I), \mathrm{Cu}(I I)$ and $\mathrm{Zn}(I I)$ Schiff base complexes with o-hydroxy benzylidene-1-phenyl-2,3-dimethyl-4amino-3-pyrazolin-5-one », J. UmSalama for Sci., 12(2),66-70.

6.Vogel,A.I., 1956. «A Text book of practical organic chemistry ", $3^{\text {rd }}$ Ed.,Longman,pp62. 
7.Skoog,D.A., 1988. «Fundamentals of analytical chemistry», $5^{\text {th }}$ Ed., JohnWiely and Sons, New York, London, pp186

8.Collins,C.H.,and Lyne,P.M., 1970. «Microbiological methods», $3^{\text {rd }} \mathrm{Ed}$., Butter Worth and CO.Ltd.,pp203.

9.Atlas,M. R. , Alfres, E. ,Alfres, B., and Lawrence, C.P., 1995. «Laboratory manual Experimantal Microbiology», Mosby- year Book, Inc., pp96.

10. Mishra,L., and Singh,V.K., 2000. « Synthesis and antimicrobial studies of some metal complexes», Ind.J. Chem.,32(4),98-104.

11. Baker,A.J., and Cairs,T., 1967. " Spectroscopic techniques in organic chemistry», Vol.(2), Heyden and Son.Ltd.,pp233.

12. Silverstein ,R.M., Bassler, G.C., and Morrill, T.G., 1981. «Spectrometric Identification of organic Compounds», $4^{\text {th }}$ Ed. , JohnWiely and Sons,Inc., New York, London, pp188.

13. Nakamoto,K., 1997. "Infrared of Inorganic and Coordination Compounds», $6^{\text {th }}$ Ed. , John-Wiely, Inc., New York, London, pp245.

14. Kumar ,U., Singh ,C., and Mishra, K. ， 1988.«Oxovanadium (IV) complexes with thiohydrazide derivatives », J.Ind.Chem. Soc., LVII,76-81.

15. Al-Adely,K.J., 2000. «Synthesis and spectroscopic study of group (IIB) and (IIIB) metal ion complexes with new azo compounds and with 1(2-pyridylazo)2-naphthole», Ph. D. Thesis, Baghdad university, Iraq.

16. Carl Ballhausen, I., 1962. «Introduction to ligand Field Theory», New York,TorontoLondon, pp157.

17. Nicholis, D., 1984. «Complexes of First-Row transiton elements», Translated by Dr.W.I.Azeez,Mosul university, Iraq, pp89.
18. Jassim,A.H., 1993. "Synthesis and study of transition metal Complexsesof chelating heterocycles to wards the design of Biologically active compounds », $\mathrm{Ph}$. D. Thesis, Al- Nahrain university, Baghdad, Iraq.

19. Figgis,B.N., $1966 . \quad$ Introduction to ligand Field», John-Wiely and Sons,Inc.,New York, London, pp166.

20. Sutton,D., 1968. «Elecronic Spectra of Transition metal Complexes», Mc Graw-Hill publishing Compony litd ,pp89.

21. Greenwood ,N.N., and Earnchaw,A. , 1998. "Chemistry of the Elements», $2^{\text {nd }}$ Ed., Pergaman Press,pp1199.

22. Al-Hasani, R.A.M., 2004. " Synthesis and study of some transition metal Complexses with mannich bases derived from-1,2,4triazole ring », $\mathrm{Ph}$. D. Thesis, AlNahrain university, Baghdad, Iraq.

23. Lever,A.B.P., 1968. «Inorganic Electronic Spectroscopy», Elsevier Publishing Company New York, London, pp183.

24. Rao,P., and Ganorkar,M., 1988. «Synthesis and structural studies of $\mathrm{Os}(\mathrm{III}), \mathrm{Mn}(\mathrm{II}), \mathrm{Fe}(\mathrm{III}), \quad \mathrm{Co}(\mathrm{II})$, $\mathrm{Ni}(\mathrm{II})$, and $\mathrm{Cu}(\mathrm{II})$ complexes of $\mathrm{N}-(4-$ methyl -8-acetoumbeliferonylidene)$N$ (isonicotinoyl) hydrazine», Ind.J. Chem.,27A,44-51.

25. Raman,N., Esthar, S., and Thangaraja, C., 2004. «A new mannich base and its transition metal (II) complexes - synthesis, structural ,characterization and electrochemical study", J.Chem. Sci.,16(4), 148-152.

26. Surga,W.J., and Lenarcik,B., 1995. "Coordination compounds of 2mercapto-1-methylimidazol with $\operatorname{Pt}(I I), P d(I I), R h(I I I)$ and Ru(III) ", Trans.Met.Chem.,15(8),69-74.

27. Gupta,H.K., and Dikshit,S.K., 2000. «Reactions of $R u(I I), R u(I I I), \quad P t(I I)$ andPt(IV) with 2-mercapto-3-phenyl4-quinazolinone in the presence and 
absence of various $\mathrm{N}$-Heterocyclic base», J.Chem. Sci.,104(2),117-122.

28. Imran,M.,Iqbal,J., and Latif,S., 2006. «Synthesis, Characterization and invitro screening of quinoline derivative and its comlexes with $R u(I I I), R h(I I I)$, andPt(IV)», $\quad$ J.Bio. Sci., 6(5),98-108.

29. Saxena,R.C., Jain,C.L., and Benjamin, R., 1988. "Magnetic and spectral behaviour of Pd(II), Pt(IV) and $R u(I I I)$ complexes with some tridentate substituted thiosemicarbazones», J.Ind. Chem. Soc. ,LXIII,69-78.

30. Agarwal,S.K., and Saxena,R.C., 1979. "Complexes of $\mathrm{Cu}(\mathrm{II}), \mathrm{Ni}(\mathrm{II})$, $\mathrm{Co}(\mathrm{II}), \mathrm{Fe}(\mathrm{III})$ and $\mathrm{Os}(\mathrm{III})$ with 4-pdimethylamino-anilino-3-penten-2one», J.Ind.Chem. Soc., LVI,101-112.

31. Gajendr,M.R., and Agarwala,U.A., 2000. «Complexing behaviour of 1,3,4-thiadiazole-2-thiol-5-amino

with $\mathrm{Fe}(I I), \quad \mathrm{Co}(I I), R u(I I), \quad R u(I I I)$ ,Pd(IV) ,Ir(III) and Pt(IV) », .Inorg.Nucl.Chem.,37(3),88-94.

32. Anjane, Y., and Rao,R., 1986. «Synthesis and antimicrobial studies of some metal complexes", Synth.React.Inorg.Met.Org.Chem.,16 (3), 92-101.

33. Mishra,L., and Singh,V., $1998 . \ll$ Synthesis and antimicrobial studies of some metal complexes», Ind.J. Chem.,32(8), 32-38.

34. Tweedy,B.G., 1985. «Phytopathology and Antibiotic ascientific approach» $1^{\mathrm{St}}$ Ed.,Mir Publishers, pp208.

35. Dharmaraj,N., $\quad 2001 . « R u t h e n i u m$ (II)complexes containing bidentate schiff bases and their antifungal activity », Trans.Met. Chem., 26(10), 53-59.

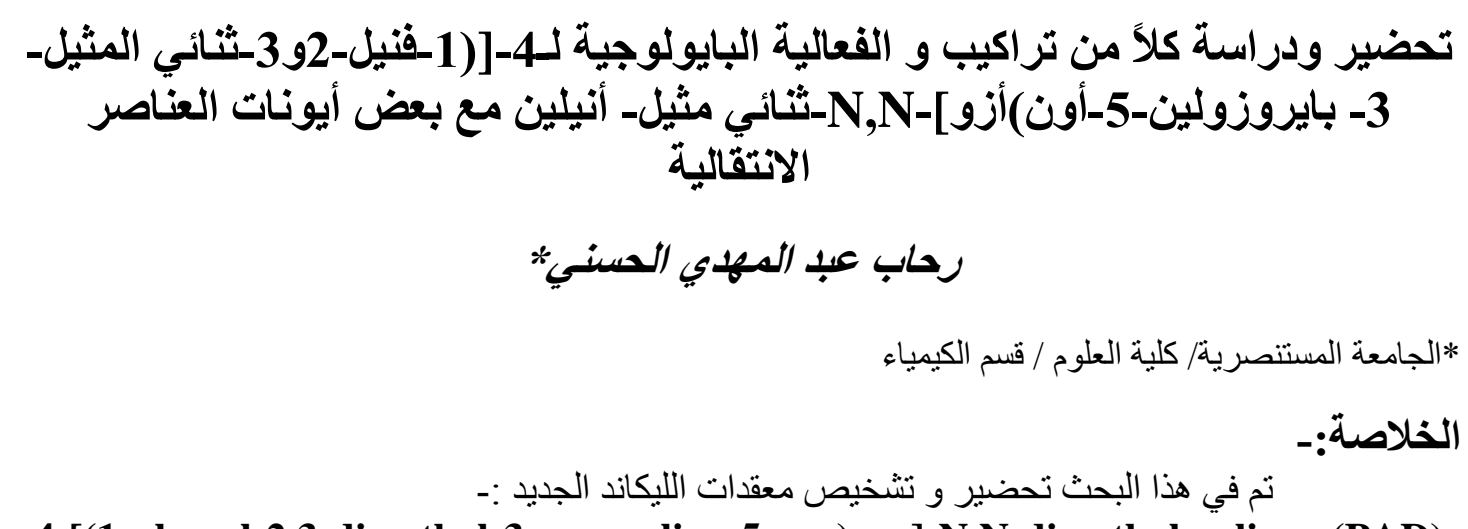

4-[(1-phenyl-2,3-dimethyl-3-pyrozoline-5-one)azo]-N,N-dimethyl anline (PAD) للعناصر الإنتقالية الكوبلت (II) و النيكل (II) و البلاديوم(II) والكروم (III) و الحديد (III) و (III) و الروثينيوم

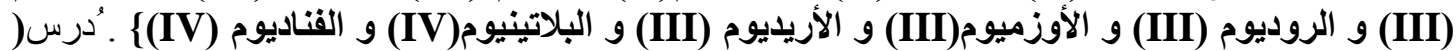

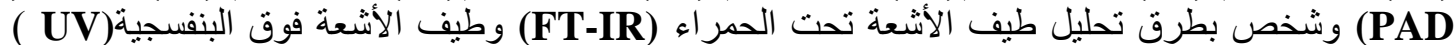
و التحليل الدقيق للعناصر(C.H.N),في حين شُخصت المعقدات المحضرة وتم إقتر اح الثكل الهندسي لها بالحالة

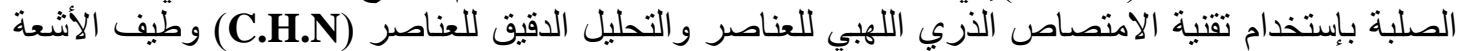

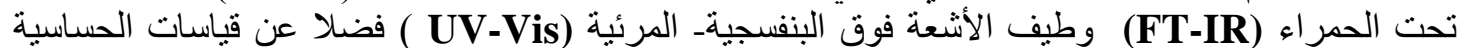

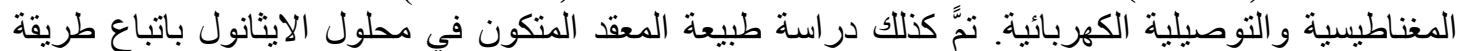

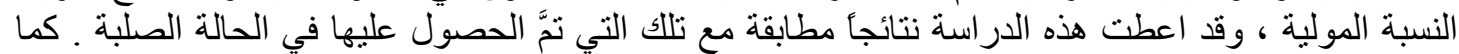

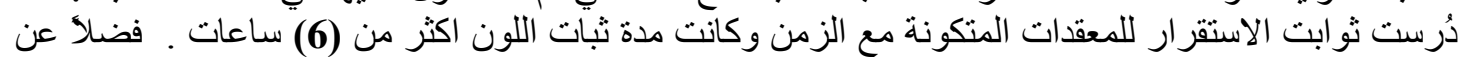

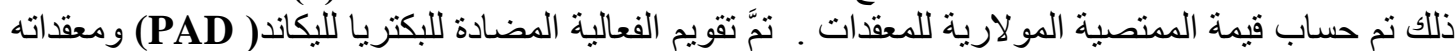

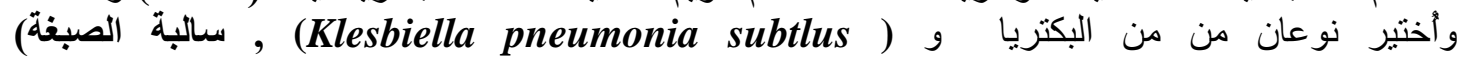

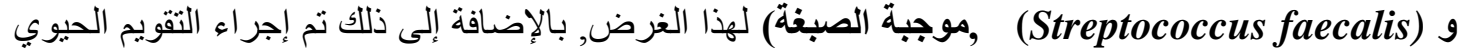
لليكاند ومعقداته ضد نو عين من الفطريات (Candida albicans)وو(Aspergillus flavus) . 